\title{
Effect of Temperature of Spark Plasma Sintering on the Development of Oxide Compound in Fe-25wt\%Ni-17wt\% CrAustenitic Stainless Steel
}

\author{
S. Mustofa $^{1 *}$, M. Dani ${ }^{1}$, Parikin ${ }^{1}$, T. Sudiro ${ }^{2}$, B. Hermanto ${ }^{2}$, D. R. Adhika ${ }^{3,4}$, Syahbuddin ${ }^{5}$, C. A. Huang ${ }^{6}$ \\ ${ }^{1}$ Center for Sci. and Tech. of Adv. Materials, BATAN, KawasanPuspiptekSerpong, South Tangerang 151314, \\ Indonesia \\ ${ }^{2}$ Research Center of Physics-LIPI, Kawasan Puspiptek Serpong, South Tangerang 15314, Indonesia \\ ${ }^{3}$ Research Center for Nanosciences and Nanotechnology, Bandung Institute of Tech., Jl. Ganesha 10, Bandung \\ 40132, Indonesia \\ ${ }^{4}$ Adv. Functional Mat. Res. Group, Fac. of Industrial Tech., Bandung Institute of Tech., Jl. Ganesha 10, Bandung \\ 40132, Indonesia \\ ${ }^{5}$ Dept. of Mechanical Eng., Fac. of Eng., Pancasila University, Srengseng Sawah, Jagakarsa, South Jakarta 12640, \\ Indonesia \\ ${ }^{6}$ Dept. of Mechanical Engineering, Chang Gung University, Taoyuan, Taiwan \\ *Corresponding author: salim.mustofa@gmail.com
}

\begin{abstract}
To investigate the effect of sintering temperature of spark plasma on the development of oxide compound in Fe-25wt $\% \mathrm{Ni}-17 \mathrm{wt} \% \mathrm{Cr}$ austenitic stainless steels (ASS).The ingredient samples were high purity powder of $\mathrm{Fe}, \mathrm{Ni}$ and $\mathrm{Cr}$ and mixed by through milling process for 5 hours. Compacting the three elements under $30 \mathrm{MPa}$ and vacuum was carried out in a spark plasma sintering (SPS) machine at temperature of 900 and $950^{\circ} \mathrm{C}$ for 5 minutes. The microstructure of $\mathrm{Fe}-25 \mathrm{wt} \% \mathrm{Ni}-17 \mathrm{wt} \% \mathrm{Cr}$ ASS including oxide compound layer was examined through an Optical Microscope (OM), a Scanning Electron Microscope (SEM) and a Transmission Electron Microscope (TEM) equipped with Energy Dispersive Spectrometers (EDS), and also by Raman Spectroscopy.The crystal structure of austenite grains in the matrix was identified using X-Ray Diffractometer. Although, the SPS can consolidate nano alloy, the Fe-25wt $\%$ Ni-17wt $\%$ Cr ASS consists of matrix of fine austenite, g-FeNi grains and particles of a'-Cr. Sintering temperature at $950^{\circ} \mathrm{C}$ increase $\mathrm{O}$ content in the surface of Fe-25wt $\% \mathrm{Ni}-17 \mathrm{wt} \% \mathrm{Cr}$ ASS that mainly related to increasing the distribution of very fine a'-Cr particles as $\mathrm{CrO}$ compound beside of increasing the trapped air bubbles. The Raman spectra of Cr-rich $\mathrm{M}_{2} \mathrm{O}_{3}$ was identified (M: Metal) at sintering temperature of $950^{\circ} \mathrm{C}$, while the Fe-rich $\mathrm{M}_{2} \mathrm{O}_{3}$ and pure $\mathrm{Fe}_{3} \mathrm{O}_{4}$ without significant amount of dissolved chromium or nickel in a main band at $671 \mathrm{~cm}^{-1}$ was identified at $900^{\circ} \mathrm{C}$. The existence of $\mathrm{g}-\mathrm{Fe}_{2} \mathrm{O}_{3}$ and $\mathrm{a}-\mathrm{Fe}_{2} \mathrm{O}_{3}$ was also successfully detected from the Raman.Changes in the number of particles with high $\mathrm{Cr}$ content or a'-Cr in the matrix with fine grains of $\mathrm{g}-\mathrm{FeNi}$ formed during the process of sintering by spark plasma makes more oxide compounds in the $\mathrm{Fe}-25 \mathrm{Ni}-17 \mathrm{Cr}$ ASS at $950^{\circ} \mathrm{C}$ as compared to sintering temperature at $900^{\circ} \mathrm{C}$.
\end{abstract}

The oxide compound is formed from the reaction of $\mathrm{O}$ and $\mathrm{Cr}$ content in a'-Cr particles during process of spark plasma sintering.

Key words :Fe-25wt\%Ni-17wt\%Cr austenitic stainless steel, Spark Plasma Sintering, Microstructure, XRD, SEM, TEM, Raman Spectroscopy.

\section{INTRODUCTION}

Austenitic stainless steel is utilized in the environment of high temperature due to its excellent properties such as high strength, corrosion and creep resistances. In now days, techniques to produce the stainless steel has developed rapidly to new sintering process by spark plasma method. This technique can be used to consolidated powder materials, that is consider fast as compared to conventional sintering processes. Moreover, the results of this fabrication are very promising by high homogeneity, high density and low porosity. Thus, one of austenitic stainless steel which developed like SS 316L has been synthesized by using this technique in some studies [1-6]. However, focus of those study is in the development of microstructure and its properties related. Rarely or no intension has been done in the surface corrosion of the ASS. Thus, this study will find out the behavior of oxide compounds in the surface of ASS.

\section{EXPERIMENTAL PROCEDURE}

High purity metal powders of $\mathrm{Fe}, \mathrm{Ni}$ and $\mathrm{Cr}$ are used for consolidating the Fe-25wt\%Ni-17wt\%Cr ASS using Spark Plasma Sintering (SPS). The composition of those elements is $58.00 \%$ for $\mathrm{Fe}, 25.00 \%$ for $\mathrm{Ni}$ and $\mathbf{1 7 . 0 0 \%}$ for Cr. Starting with mixing the three ingredients milled in rotation of $\mathrm{rpm}$ for 5 hours. Then it was compacted under a load of $30 \mathrm{MPa}$ to produce a coin of $15 \mathrm{~mm}$ in diameter and $2.5 \mathrm{~mm}$ thick and sintered under vacuum at temperature of $900 \mathrm{C}$ and $950^{\circ} \mathrm{C}$ for 
S. Mustofa et al., International Journal of Emerging Trends in Engineering Research, 8(9), September 2020, 5661 - 5667

5 minutes in a SPS machine the facility of SPS Fuji-625 (Fuji Electronic Industrial Co., Ltd.).

In order to examine the crystal structure of matrix of Fe-25wt $\%$ Ni-17wt $\%$ Cr ASS, it was employed PAN analytical X'pert Pro X-ray diffractometer mounted with a $\mathrm{Cu}$-Kaof 1,5405 A. The coin was also prepared to release its microstructure through a standard metallographical processes including grinding, polishing and etchant. The microstructure of $\mathrm{Fe}-25 \mathrm{wt} \% \mathrm{Ni}-17 \mathrm{wt} \% \mathrm{Cr}$ ASS was observed through an Optical Microscope (OM) and a Scanning Electron Microscope (SEM; JSM-7600F, Jeol Ltd., Tokyo, Japan) operated at voltage of $20 \mathrm{kV}$ and a Transmission Electron Microscope (TEM) of Hitachi H-9500 operated at a voltage of $300 \mathrm{kV}$ which are each attached by Energy Dispersive Spectroscopy (EDS). Thin foil for TEM was prepared using micro sampling method on Focused Ion Beam (FIB) Hitachi FB-2200 at an operating voltage of $40 \mathrm{kV}$. Moreover, the development of oxide compounds formed on the surface of Fe-25wt $\% \mathrm{Ni}-17 \mathrm{wt} \% \mathrm{Cr}$ ASS after sintering at 900 and $950^{\circ} \mathrm{C}$ for 5 minutes was examined by using Raman Spectroscopy (RS).

\section{RESULTS AND DISCUSSION}

\subsection{Microstructure of $\mathrm{Fe}-25 \mathrm{wt} \% \mathrm{Ni}-17 \mathrm{wt} \% \mathrm{Cr}$ ASS}

$\mathrm{X}$-ray diffraction patterns from the Fe-25wt $\% \mathrm{Ni}-17 \mathrm{wt} \% \mathrm{Cr}$ ASS synthesized at 900 and $950^{\circ} \mathrm{C}$ via spark plasma sintering are shown in Figure 1. Prominent peaks related to (111), (200), (220), (311), (222) and (331) planes are presented in both the x-ray diffraction patterns. The prominent peaks indicated that its crystal structure of this steel is a face-centered cubic which is included in the Fm4m space group. Lattice parameter of the structures was determined about $3.5877 \AA$ after sintering temperature at $900^{\circ} \mathrm{C}$ and about $3.5876 \AA$ after sintering temperature at $950^{\circ} \mathrm{C}$ for 5 minutes. Some studies $[7,8]$ were succeeded to find the same value although they used different methods to prepare their $\mathrm{FeNi}(\mathrm{Cr})$ samples. No other peaks that are related to other phases were found in these x-ray diffraction patterns. Thus, the matrix of $\mathrm{Fe}-25 \mathrm{Ni}-17 \mathrm{Cr}$ ASS can determined to be austenite phase of $\mathrm{g}-\mathrm{NiFe}$.

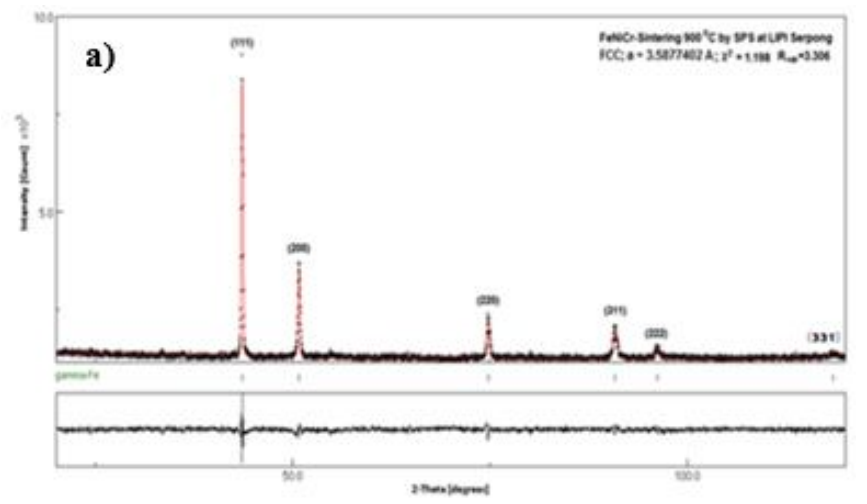

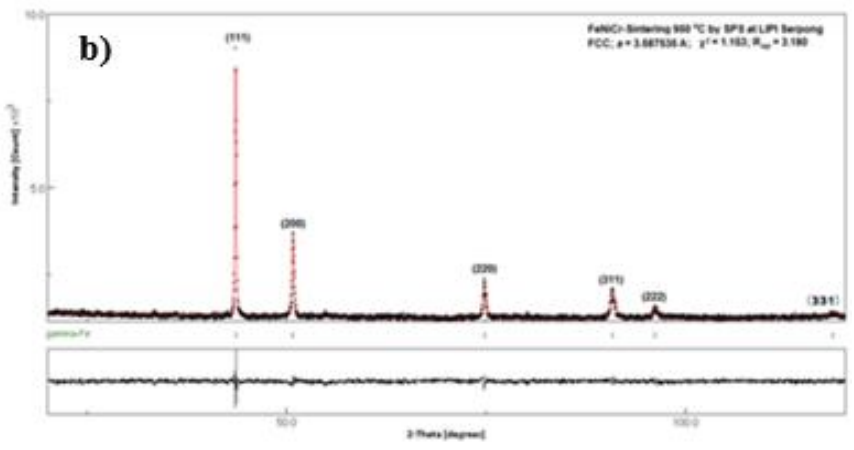

Figure 1: XRD patterns generated from $\mathrm{Fe}-25 \mathrm{wt} \% \mathrm{Ni}-17 \mathrm{wt} \% \mathrm{Cr}$ ASS formed after sintering at a) 900 and b) $950^{\circ} \mathrm{C}$ for 5 minutes.

As seen in Figure 2, the microstructure of Fe-25wt $\% \mathrm{Ni}-17 \mathrm{wt} \% \mathrm{Cr}$ ASS after spark plasma sintering at 900 and $950^{\circ} \mathrm{C}$ for 5 minutes is found to consist of matrix composing by austenite fine grains and fine particles of $\mathrm{FeNiCr}$ intermetallic compounds. Such formation after sintering at $900^{\circ} \mathrm{C}$ seems to have fine grains and more refine after sintering at $950^{\circ} \mathrm{C}$. Increasing the sintering temperature leads the distribution of very fine particles higher in the matrix. Figure 3 presents increasing the numbers of very fine particles (particle diameter $\leq 1 \mathrm{~mm}$ ) almost double time after sintering at higher temperature. Thus, more high sintering temperature (from $900^{\circ} \mathrm{C}$ to $950^{\circ} \mathrm{C}$ ) has contributed to the development of formation of $\mathrm{Fe}-25 \mathrm{wt} \% \mathrm{Ni}-17 \mathrm{wt} \% \mathrm{Cr}$ ASS. The microstructure formed at $900^{\circ} \mathrm{C}$ consists of matrix of fine austenite grains and fine particles of $\mathrm{FeNiCr}$ intermetallic compound speeded in the matrix while sintering at $950^{\circ} \mathrm{C}$ forms very fine grains in the matrix and fine particles which distributed more in number.
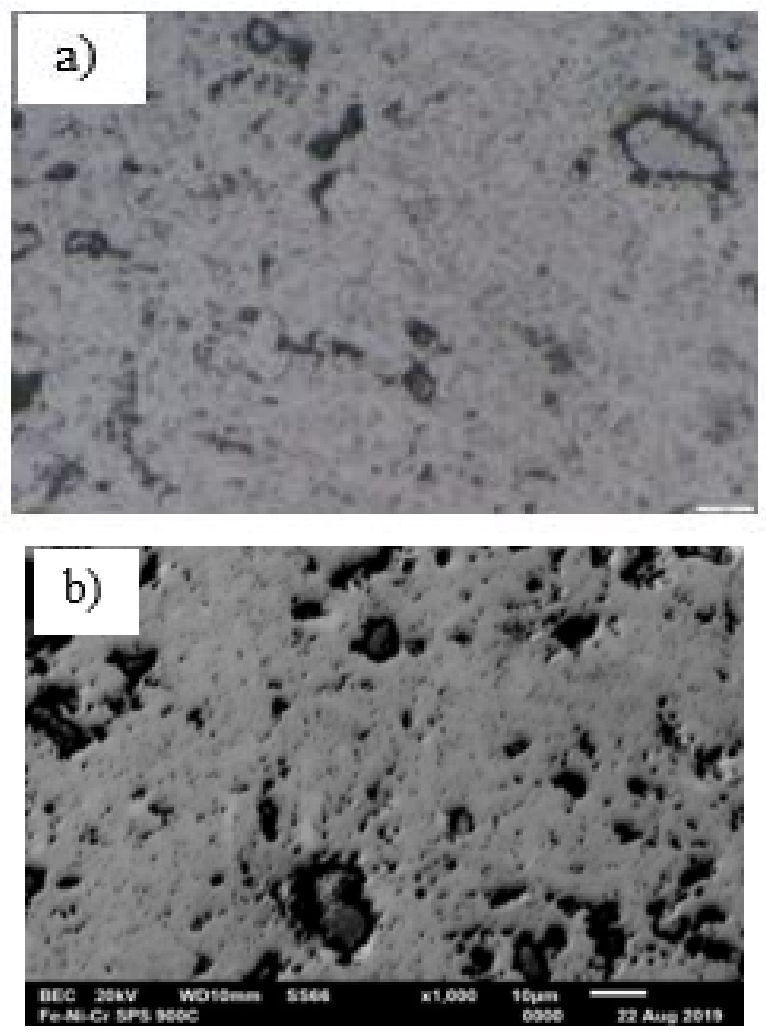
S. Mustofa et al., International Journal of Emerging Trends in Engineering Research, 8(9), September 2020, $5661-5667$
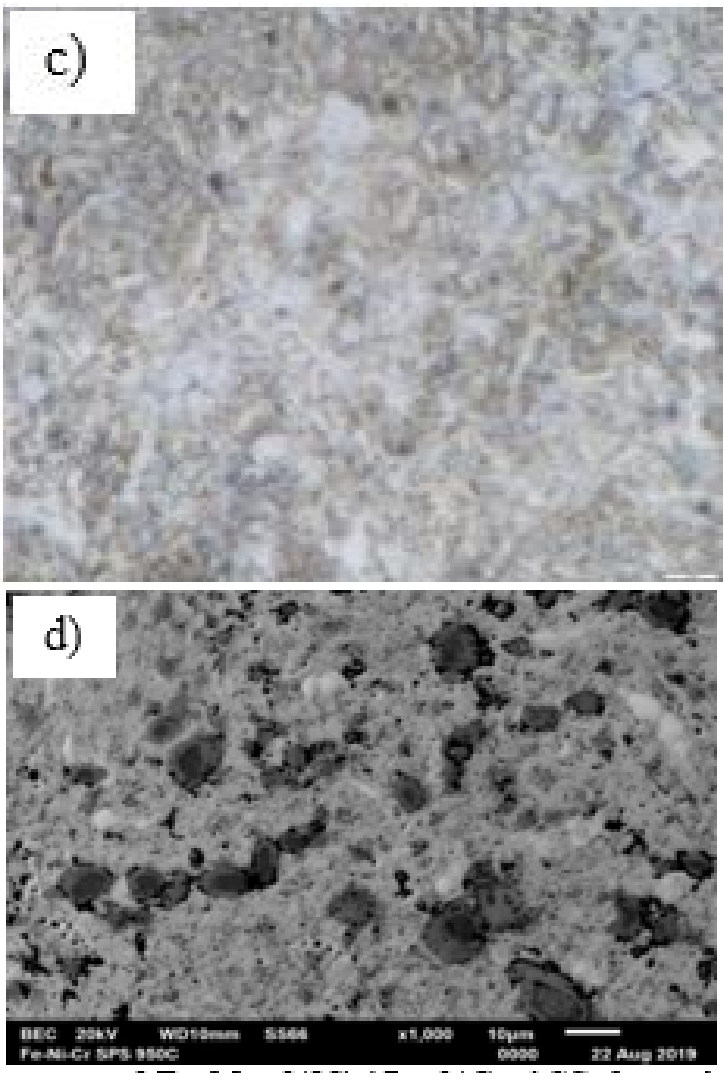

Figure 2: Optical and SEM micrographs showing the microstructure of $\mathrm{Fe}-25 \mathrm{wt} \% \mathrm{Ni}-17 \mathrm{wt} \% \mathrm{Cr}$ ASS formed after sintering at a-b) $900^{\circ} \mathrm{C}$ and $\mathrm{c}-\mathrm{d}) 950^{\circ} \mathrm{C}$ for 5 minutes

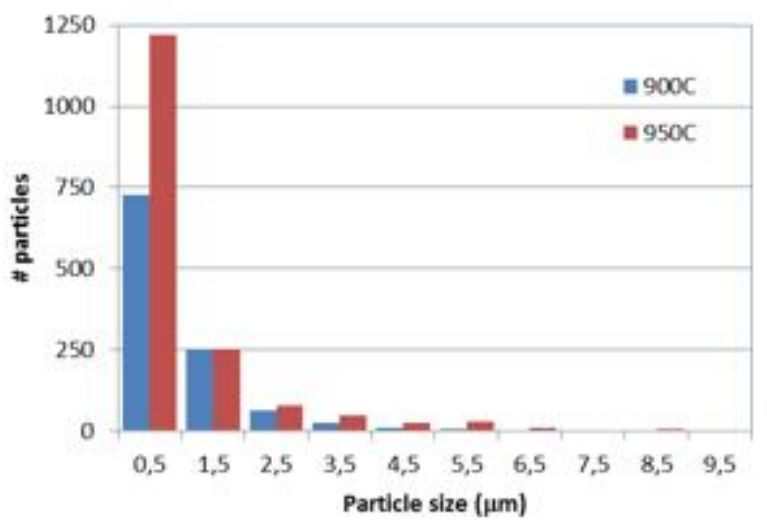

Figure 3: Distribution of particles of intermetallic compounds scattered on the Fe-25wt\% Ni-17wt\%Cr ASS formed after SPS at 900 and $950^{\circ} \mathrm{C}$ for 5 minutes

SEM micrograph and EDS result for matrix containing particles are displayed in Figure 4. Element contents in a matrix containing particles identified using EDS was $0 \% \mathrm{C}$, $2.71 \% \mathrm{O}, 19.92 \% \mathrm{Cr}, 53.76 \% \mathrm{Fe}, 23.79 \% \mathrm{Ni}$ after sintering at temperature $900^{\circ} \mathrm{C}$ while the matrix formed after sintering at temperature $950^{\circ} \mathrm{C}$ has $3.18 \% \mathrm{C}, 3.37 \% \mathrm{O}, 23.75 \% \mathrm{Cr}, 50.27$ $\% \mathrm{Fe}, \quad 19.43 \% \mathrm{Ni}$. Thus, $\mathrm{O}$ content in the $\mathrm{Fe}-25 \mathrm{wt} \% \mathrm{Ni}-17 \mathrm{wt} \% \mathrm{Cr}$ ASS sintered at $950^{\circ} \mathrm{C}$ is higher as compared to the ASS sintered $900^{\circ} \mathrm{C}$.
Particle

Matrix + particles

Particle

Matrix + particles $\quad 3.18 \% \mathrm{C}, 3.37 \% \mathrm{O}, 23.75 \% \mathrm{Cr}, 50.27 \% \mathrm{Fe}, 19.43 \% \mathrm{Ni}$
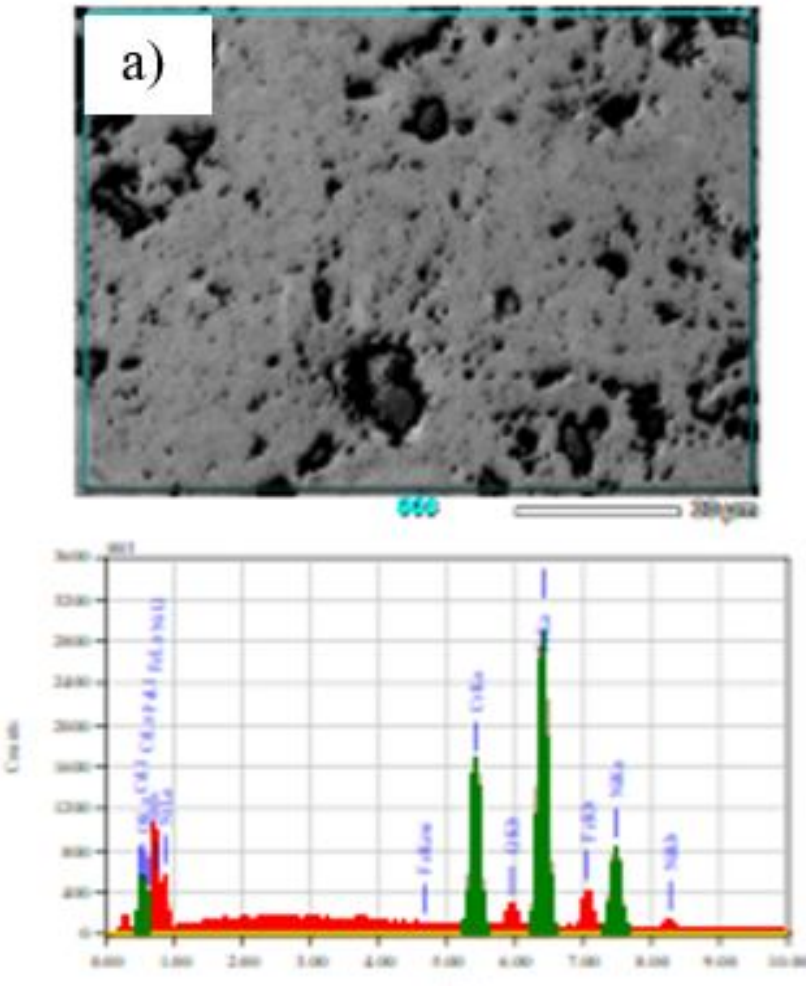

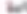
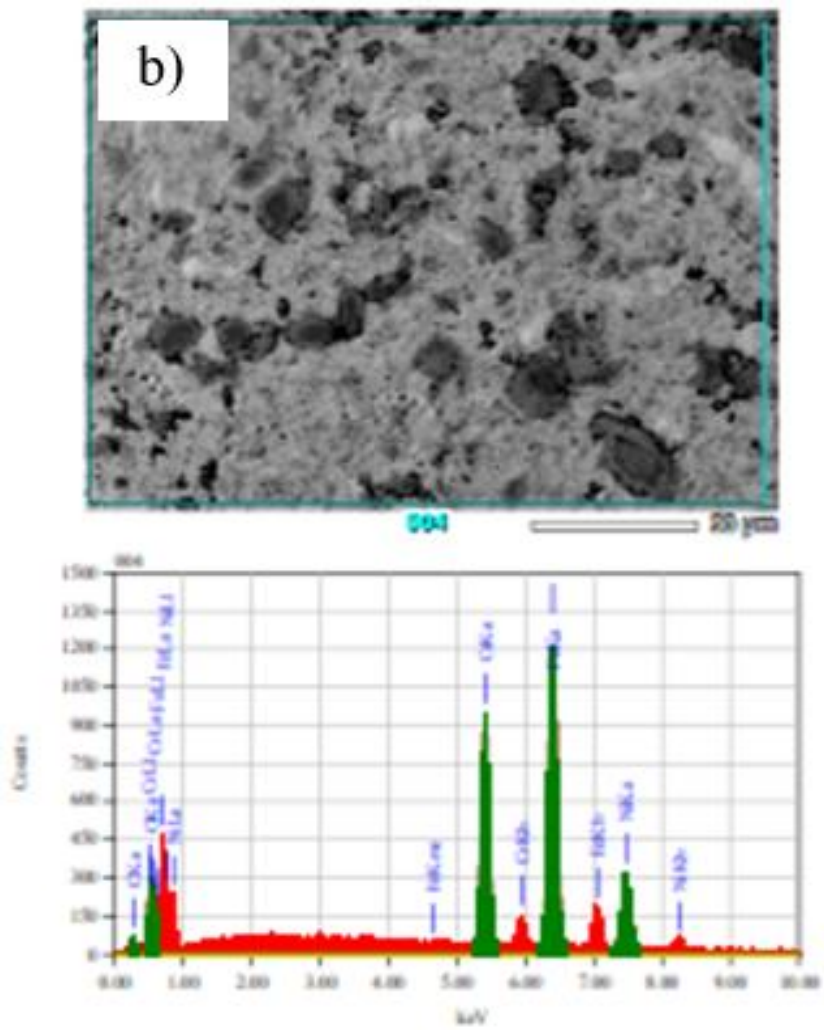

Figure 4: SEM micrograph and EDS result for matrix +particles in the Fe-25wt\%Ni-17wt\% Cr ASS formed after sintering at a) 900 and $950^{\circ} \mathrm{C}$ for 5 minutes 

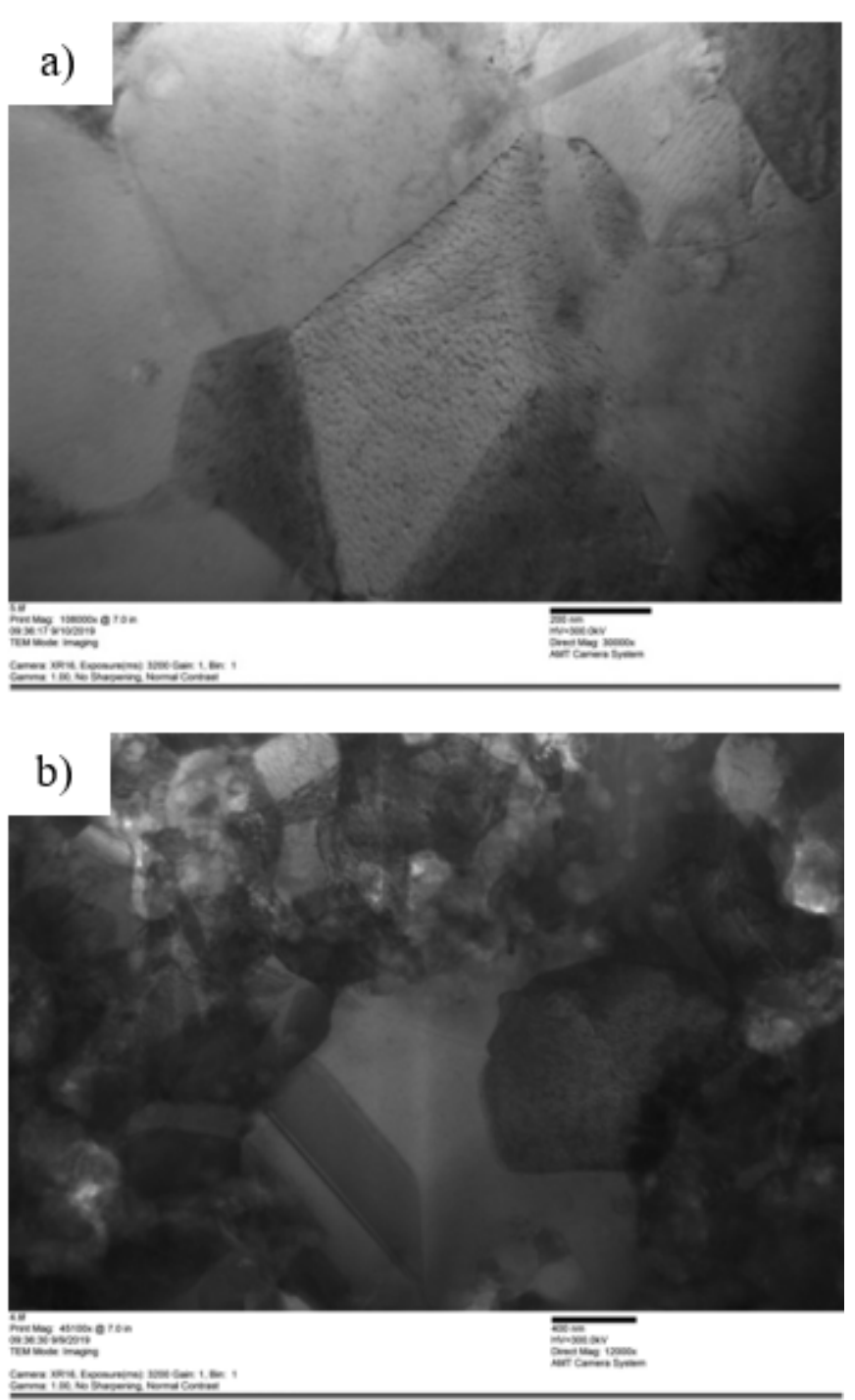

Figure 5: TEM Images $\mathrm{Fe}-25 \mathrm{wt} \% \mathrm{Ni}-17 \mathrm{wt} \% \mathrm{Cr}$ ASS formed after sintering at a) 900 and $950^{\circ} \mathrm{C}$ for 5 minutes

Figure 5 are TEM images taken from the Fe-25wt $\% \mathrm{Ni}-17 \mathrm{wt} \% \mathrm{Cr}$ ASS sintered at temperature of 900 and $950^{\circ} \mathrm{C}$ for 5 minutes. Some air bubbles are found in the interior and boundary of austenite grains. Such air bubbles increased in number as increasing the sintering temperature to $950^{\circ} \mathrm{C}$. Thus, it is clear that air bubbles trapped more higher after sintering at higher temperature.

\subsection{Development of Oxide Compounds}

Raman analysis was performed using a FT-Raman Senterra (Bruker) with an argon laser (wavelength $532 \mathrm{~nm}$, power 20 $\mathrm{mW}$ ), with a spatial resolution of $1 \mu \mathrm{m}$. The spectra of oxide phases in the $\mathrm{Fe}-\mathrm{Cr}-\mathrm{O}$ system interpreted using the work of McCarty and Boehme [9], who studied Raman signatures of the spinel- $\left(\mathrm{Fe}_{3-\mathrm{x}} \mathrm{Cr}_{\mathrm{x}} \mathrm{O}_{4}\right)$ and corundum-type $\left(\mathrm{Fe}_{2-\mathrm{x}} \mathrm{Cr}_{\mathrm{x}} \mathrm{O}_{3}\right)$ solid solutions.
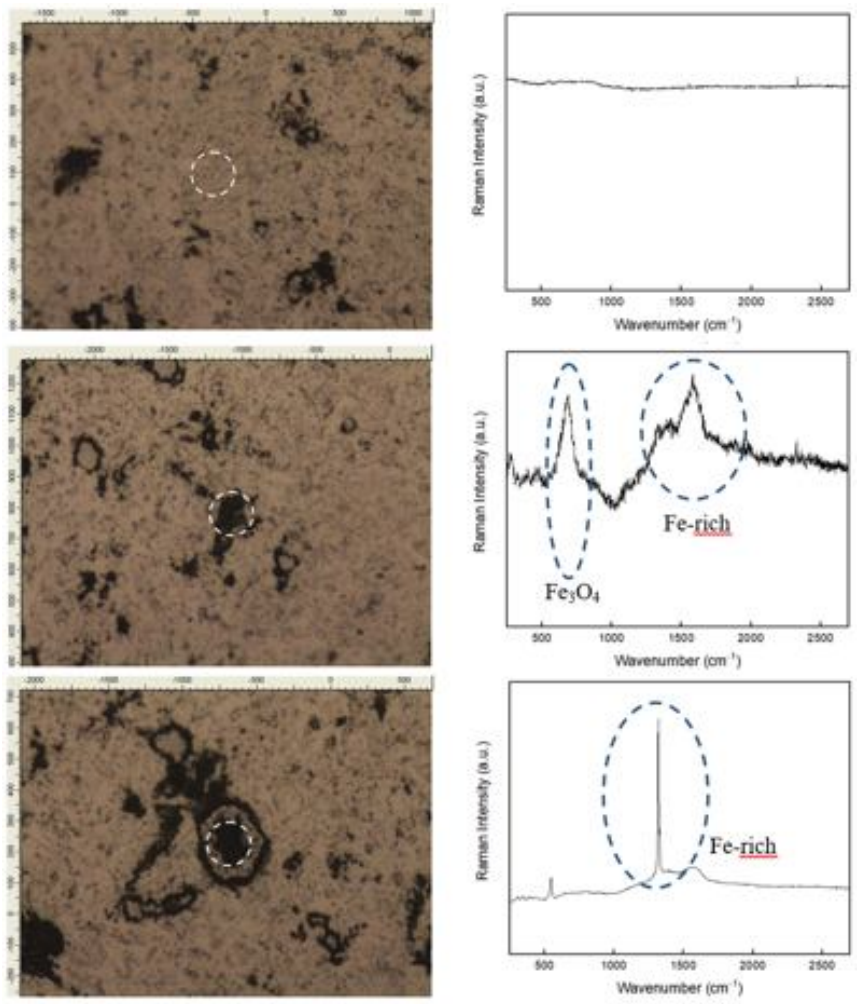

Figure 6: Raman intensity of $\mathrm{Fe}-25 \mathrm{wt} \% \mathrm{Ni}-17 \mathrm{wt} \% \mathrm{Cr}$ ASS sintered by SPS at temperature of $900^{\circ} \mathrm{C}$ for 5 minutes
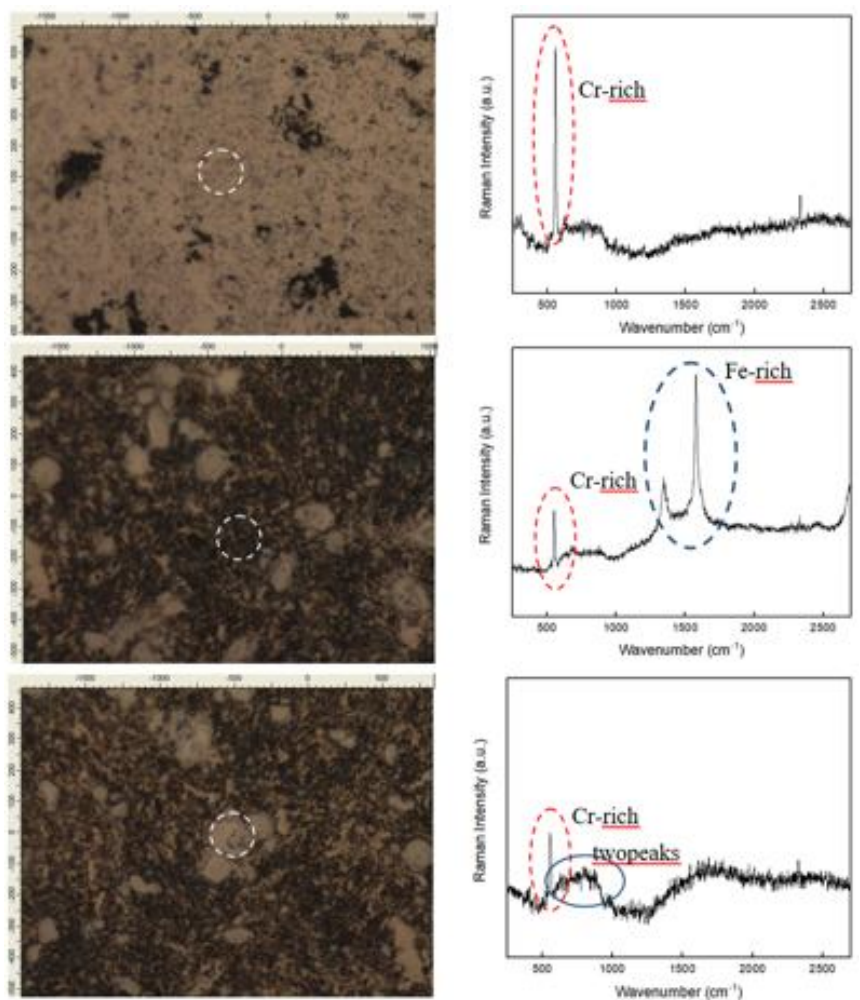

Figure 7: Raman intensity of Fe-25wt $\% \mathrm{Ni}-17 \mathrm{wt} \% \mathrm{Cr}$ ASS sintered by SPS at temperature of $950^{\circ} \mathrm{C}$ for 5 minutes 
S. Mustofa et al., International Journal of Emerging Trends in Engineering Research, 8(9), September 2020, 5661 - 5667

Figure 6 and 7 shows Raman spectrum of a) sintered sample that was obtained from SPS at temperature of $900^{\circ} \mathrm{C}$, and b) at temperature of $950^{\circ} \mathrm{C}$. In the all areas (see Figure 7) of surface sintered sample at temperature of $950^{\circ} \mathrm{C}$, the Raman spectra of Cr-rich $\mathrm{M}_{2} \mathrm{O}_{3}$ (marked a dotted red line) is identified (M: Metal), and this spectrum was not found in the case of $900^{\circ} \mathrm{C}$. In contrast to the temperature $900^{\circ} \mathrm{C}$, the $\mathrm{Fe}$-rich $\mathrm{M}_{2} \mathrm{O}_{3}$ spectrum was identified (see Figure 6). The Raman spectrum of a main band at $671 \mathrm{~cm}^{-1}$, is the characteristic of pure $\mathrm{Fe}_{3} \mathrm{O}_{4}$, with no significant amount of dissolved chromium or nickel. These phases are all consistent with the compositions determined with SEM-EDS and XRD. Considering Raman, $\mathrm{XRD}$ and EDS results, it assumed that the $\mathrm{Cr}$ element at the bottom is pushed up to the surface at temperature of $950^{\circ} \mathrm{C}$ and formed Cr-rich $\mathrm{M}_{2} \mathrm{O}_{3}$ [9]. The Raman spectrum at temperature of $950^{\circ} \mathrm{C}$ that is marked with a blue circle shows a broad band which can be divided into two peaks at around 690 and $734 \mathrm{~cm}^{-1}$. The peak of $690 \mathrm{~cm}^{-1}$ can be associated with a Cr-rich $\mathrm{Fe}-\mathrm{Cr}$ spinel [10] or $\mathrm{NiCr}_{2} \mathrm{O}_{4}$ [10], and the peak of 734 $\mathrm{cm}^{-1}$ can be linked with $\mathrm{NiFe}_{2} \mathrm{O}_{4}[10]$. Even so, there are still some uncertainties from the results of Raman and EDS, where there might be also contains $\mathrm{NiFe}_{2} \mathrm{O}_{4}-\mathrm{FeCr}_{2} \mathrm{O}_{4}$ mixture and showed no internal oxidation. Similar with the $\mathrm{Fe}-25 \mathrm{Cr}-17 \mathrm{Ni}$ alloy, the $\mathrm{Fe}-25 \mathrm{Cr}-17 \mathrm{Ni}$ alloy occasionally developed intergranular carbides, but from the result there is no found intergranular carbides and no carburization in any of the process of SPS, either $900^{\circ} \mathrm{C}$ or $950^{\circ} \mathrm{C}$.

The results of Raman's analysis this time, the other possibility of the sintering results from the $\mathrm{Fe}-\mathrm{Ni}-\mathrm{Cr}$ alloy sample is the formation of $\mathrm{NiFe}_{\mathrm{x}} \mathrm{Cr}_{2 \mathrm{x}} \mathrm{O}_{4}$, that was reported from another researchers regarding with $\mathrm{Ni}-\mathrm{Cr}-\mathrm{Fe}$ ternary system [11-15]. The Raman spectrum of Fe-rich at around $1500 \mathrm{~cm}^{-1}$ in this study is very close to [13], which is maybe showing the presence of $\mathrm{g}-\mathrm{Fe}_{2} \mathrm{O}_{3}$ and $\mathrm{a}-\mathrm{Fe}_{2} \mathrm{O}_{3}$. Spectrum of a- $\mathrm{Fe}_{2} \mathrm{O}_{3}$ is usually excited at around 300 and $500 \mathrm{~cm}^{-1}$, but at $532 \mathrm{~nm}$ of laser Raman this time, the spectrum Raman is observed at around 650 and $1500 \mathrm{~cm}^{-1}$. This is attributed to a

disorder-activated longitudinal optical (LO) phonon mode. This normally Raman-forbidden mode has been reported in the Raman spectra of polycrystalline $\mathrm{a}-\mathrm{Fe}_{2} \mathrm{O}_{3}[16]$ and $(\mathrm{Fe}, \mathrm{Cr})_{2} \mathrm{O}_{3}$ alloys [17] and attributed to disorder-induced breakdown of the selection rules. The peak at around 1400 $\mathrm{cm}^{-1}$ is assigned to second order LO (2LO) phonon scattering $[16,18]$. The difference between the peak of Maslar's work and in this study, it would be caused by a difference in laser wavelength and crystallinity of the reference powders used in this study. Maslar et al. used black $\mathrm{NiO}$ powers but there are no information about purity, and irradiated by $647.1 \mathrm{~nm}$ krypton ion laser, and in this study use $532 \mathrm{~nm}$ of laser for Raman analysis. The peaks exhibited at around 600 (written as Cr-rich) is assumed as the spectrum of $\mathrm{Cr}_{2} \mathrm{O}_{3}$, as reported by [19]. According to Hosterman's work [15], the Raman spectra of the $\mathrm{NiFe}_{\mathrm{x}} \mathrm{Cr}_{2 \mathrm{x}} \mathrm{O}_{4}$ spinel series have five Raman-active modes, and all spinel series except $\mathrm{NiCr}_{2} \mathrm{O}_{4}$ show similar features in the spectra. The Raman spectra also show the peaks of $\mathrm{NiCr}_{2} \mathrm{O}_{4}$. It should be noted, however, that $\mathrm{Cr}$ oxide is most likely present underneath the $\mathrm{Ni}-\mathrm{Cr}$ spinel oxide surface layer.

Sintering of high purity powder of 58\% Fe, $25 \% \mathrm{Ni}$ and $17 \%$ $\mathrm{Cr}$ at temperatures of 900 and $950^{\circ} \mathrm{C}$ for 5 minutes has been succeeded to fabricate an $\mathrm{Fe}-25 \mathrm{Ni}-17 \mathrm{Cr}$ austenitic stainless steel consisting of a matrix with fine grains of austenite $\mathrm{g}-\mathrm{FeNi}$ and $\mathrm{a}^{\prime}-\mathrm{Cr}$ particles scattered on the interior and boundary of austenite grains. The fine grains of the austenitic g-FeNi matrix are confirmed by the results of the calculation of x-ray diffraction pattern to have a crystal structure of face-centered cubic which is included in the Fm3m space group. The lattice parameters of crystal structure is about $3.5877 \AA$ as resulted from sintering at $900^{\circ} \mathrm{C}$ and $3.5876 \AA$ as resulted from sintering at $950^{\circ} \mathrm{C}$. These measurements are in agreement with some previous studies [8],[20]-[22] in determining the matrix of austenitic stainless steels and superalloys. In the basis of composition and electron diffraction patterns, fine particles of $\mathrm{FeNiCr}$ compounds that are evenly distributed in the interior and boundaries of austenite grains as reported by Dani et al [20] are particles containing high $\mathrm{Cr}$, known as a'-Cr phase. The formation of two phases in $\mathrm{Fe}-25 \mathrm{Ni}-17 \mathrm{Cr}$ ASS changes with different sintering temperatures, namely 900 and $950^{\circ} \mathrm{C}$ for the same time.

Both the Fe-25Ni-17CrASSs formed after sintering at 900 and $950^{\circ} \mathrm{C}$ have almost the same microstructure. The microstructures of ASS consist of a matrix of fine grains of austenite, $\mathrm{g}$-FeNi and fine particles containing high-Cr, a'-Cr spread evenly on the interior and grain boundaries of g-FeNi. The size of the $\mathrm{g}-\mathrm{FeNi}$ grains becomes smaller as the sintering temperature increases from 900 to $950^{\circ} \mathrm{C}$. The small size of these grains at high temperatures is expected to occur due to recrystallization process generated from the defects of dislocations and stacking faults formed during the milling and compression during the process of spark plasma sintering so that the size of austenite grain is smaller.

Despite of large number of trapped air bubbles, although the number of fine particles of $\alpha-\mathrm{Cr}$ in sized $>1 \mathrm{~mm}$ did not change much, the number of fine particles $<1 \mathrm{~mm}$ sized increased almost twice as much as the sintering temperature increased from $900 \mathrm{C}$ to $950^{\circ} \mathrm{C}$. This result is followed by an increase in the $\mathrm{O}$ content as identified by EDS from 2.71 to $3.31 \% \mathrm{O}$. Raman results confirmed that the $\mathrm{O}$ content reacts to fine particles containing high $\mathrm{Cr}$ to form $\mathrm{CrO}$. Since the number of these particles with sized $<1 \mathrm{~mm}$ increases almost double times by increasing the sintering temperature, the number of $\mathrm{O}$ compounds the $\mathrm{Fe}-25 \mathrm{Ni}-17 \mathrm{Cr}$ ASS increases by increasing the sintering temperature from 900 to $950^{\circ} \mathrm{C}$ for each 5 minutes.

Further reading on application [23], [24], and [25] can extend research in the future. 
S. Mustofa et al., International Journal of Emerging Trends in Engineering Research, 8(9), September 2020, 5661 - 5667

\section{CONCLUSION}

Effect of the temperature of spark plasma sintering on the development of oxide compound in $\mathrm{Fe}-25 \mathrm{wt} \% \mathrm{Ni}-17 \mathrm{wt} \% \mathrm{Cr}$ austenitic stainless steels conducted in this study provides some conclusion as followed: $\mathrm{O}$ content in thin film in the surface of $\mathrm{Fe}-25 \mathrm{wt} \% \mathrm{Ni}-17 \mathrm{wt} \% \mathrm{Cr}$ ASS is higher after sintering at temperature at $950^{\circ} \mathrm{C}$ as compared to sintering at temperature at $900^{\circ} \mathrm{C}$. The Oxide compounds are mainly reacted to $\mathrm{Cr}$ to form $\mathrm{CrO}$ as particles which increasing in number as increasing the sintering temperature to $950^{\circ} \mathrm{C}$. The Raman spectra of Cr-rich $\mathrm{M}_{2} \mathrm{O}_{3}$ was identified (M: Metal) at sintering temperature of $950^{\circ} \mathrm{C}$, while the Fe-rich $\mathrm{M}_{2} \mathrm{O}_{3}$ and pure $\mathrm{Fe}_{3} \mathrm{O}_{4}$ without significant amount of dissolved chromium or nickel in a main band at $671 \mathrm{~cm}^{-1}$ was identified at $900^{\circ} \mathrm{C}$. The existence of $\mathrm{g}-\mathrm{Fe}_{2} \mathrm{O}_{3}$ and a- $\mathrm{Fe}_{2} \mathrm{O}_{3}$ was successfully detected from the Raman analysis. Likewise, $\mathrm{NiFe}_{x} \mathrm{Cr}_{2 \mathrm{x}} \mathrm{O}_{4}$ spinel. Raman results are consistent with the compositions determined with SEM-EDS and XRD. Considering Raman, $\mathrm{XRD}$ and EDS results, it is assumed that the $\mathrm{Cr}$ element at the bottom is pushed up to the surface at temperature of $950^{\circ} \mathrm{C}$ and formed Cr-rich $\mathrm{M}_{2} \mathrm{O}_{3}$.

\section{ACKNOWLEDGEMENT}

The authors would like to express their appreciation to the Head of the Center for Science and Technology for Advanced Materials, Prof. Dr. Ridwan, Head of PSTBM, Dr. Abu Khalid Rivai and Head of BTBM, Dr. Eng., IwanSumirat for their excellent support and coordinator so that this research can be finished properly. Financial support for this research was granted by Insinas Project No. 06/INS-1/PPK/E4/2019.

\section{REFERENCES}

1. E. A. Olevsky, and D. V. Dudina. Microwave SinteringIn Field-Assisted Sintering,Science and Applications, Berlin, Germany: Springer International Publishing, 2018, pp. 237-274.

2. M. Tokita. Trends in Advanced SPS Spark Plasma Sintering Systems and Technology,J. Soc. Powder Technol. Jpn, vol. 30, pp. 790-804, 1993.

3. Z. A. Munir, D. Quach, M. Ohyanagi. Electric Current Activation of Sintering: A Review of the Pulsed Electric Current Sintering Process,J. Am. Ceram. Soc, vol. 94, pp. 1-19, 2011.

4. M. Tokita. Spark Plasma Sintering (SPS) Method, Systems and Applications. In Handbook of Advanced Ceramics: Materials, Applications, Processing and Properties, 2nd ed., Somiya, S., Ed.,Waltham, MA, USA: Academic Press, 2013, pp. 1149-1178.

5. D. V. Dudina, A. K. Mukherjee. Reactive Spark Plasma Sintering: Successes and Challenges of Nanomaterial Synthesis,J. Nanomater,5, 2013.

6. M. B. Shongwe, M. M. Ramakokovhu, S. Diouf, M. O. Durowoju, B. A. Obadele, R. Sule, and P. A. Olubambi. Effect of starting powder particle size and heating rate on spark plasma sintering of FeNi alloys, Journal of Alloys and compounds, vol. 678, pp. 241-248, 2016.
7. M. Kadziolka-Gawel, W. Zarek, E. Popiel and A. Chrobar.The Crystal Structure ands Magnetic Properties of SelectedfccFeNi and Fe40Ni40B20 Alloys,ActaPhysicaPolonica A, vol. 117, no.2, pp. 412-414, 2010.

8. M. Dani, A.Dimyati, Parikin, J.G. Lesmana, A.K. Yahya, A. Insani, Syahbuddin, and C.A. Huang.Microstructure of Austenitic Stainless Steel (25Ni17Cr) Solid Treated with Different Cooling Rate, International Journal of Technology, 2019 (to be published).

9. K. McCarty and D. Boehme.A Raman Study of the Systems $\mathrm{Fe}_{3-\mathrm{x}} \mathrm{Cr}_{\mathbf{x}} \mathrm{O}_{4}$ and $\mathrm{Fe}_{2-\mathrm{x}} \mathrm{Cr}_{\mathbf{x}} \mathrm{O}_{3}$, Journal of Solid-State Chemistry, vol. 79, pp. 19-27, 1989.

10. M. da Cunha Belo, M. Walls, N. Hakiki, J. Corset, E. Picquenard, G. Sagon and D. No"el, Composition,. Structure and Properties of the Oxide Films Formed on the Stainless Steel 316L in a Primary type PWR Environment, Corrosion Science, vol. 40, pp. 447-463, 1998.

11. J.E. Maslar, W.S. Hurst, W.J. Bowers, J. H. Hendricks.In Situ Raman Spectroscopic Investigation of Stainless Steel Hydrothermal Corrosion, Corrosion, vol. 58, no. 9,pp. 739-747, 2002.

12. J. Xu, T. Shoji. The Corrosion Behavior of Alloy 182 in a Cyclic Hydrogenated and Oxygenated Water Chemistry in High Temperature Aqueous Environment, Corrosion Science, vol. 104, pp. 248-259, 2016.

13. J. E. Maslar, W. S. Hurst, T. A. Vanderah and I. Levin, The Raman spectra of $\mathrm{Cr}_{3} \mathrm{O}_{8}$ and $\mathrm{Cr}_{2} \mathrm{O}_{5}$, J. Raman Spectrosc, vol. 32, p. 201-206, 2001.

14. F. Wang.In-situ Surface Enhanced Raman Spectroscopy Investigation of the Surface Films on Alloy 600 and Alloy 690 in Pressurized Water Reactor-Primary Water, Ph.D thesis, University of California, Berkeley, 2012.

15. B. D. Hosterman.Raman Spectroscopic Study of Solid Solution Spinel Oxides, Ph.D thesis, University of Nevada, Las Vegas, 2011.

16. M. J. Massey, U. Baier, R. Merlin, and W. H. Weber.Effects of Pressure and Isotopic Substitution on the Raman Spectrum of a-Fe $\mathrm{O}_{3}$ : Identification of Two-Magnon Scattering, Phys. Rev. B, vol. 41, p. 7822, 1990.

17. K. F. McCarty and D. R. Boehme.A Raman Study of the Systems $\mathrm{Fe}_{3-\mathrm{x}} \mathrm{Cr}_{\mathrm{x}} \mathrm{O}_{4}$ and $\mathrm{Fe}_{2-\mathrm{x}} \mathrm{Cr}_{\mathrm{x}} \mathrm{O}_{3}$, J. Solid State Chem., vol. 79, no. 1, p. 19-27, 1989.

18. K. F. McCarty.Inelastic Light Scattering in $\mathbf{a}-\mathbf{F e}_{2} \mathbf{O}_{3}$ : Phonon vs Magnon Scattering, Solid State Commun., vol. 68, no.8, p. 799-802, 1988.

19. J. Kim, K. J. Choi, C. B. Bahn, J. H. Kim.In situ Raman Spectroscopic Analysis of Surface Oxide Films on Ni-base Alloy/Low Alloy Steel Dissimilar Metal Weld Interfaces in High-Temperature Water, Journal of Nuclear Materials, vol. 449, pp. 181-187, 2014.

20. M. Dani, S. Mustofa, Parikin et al. Effect of Spark Plasma Sintering (SPS) at Temperatures of 900 and $\mathbf{9 5 0}^{\circ} \mathrm{C}$ for 5 Minutes on Microstructural Formation of Fe-25Ni-17Cr Austenitic Stainless Steel, 2019 (to be published). 
S. Mustofa et al., International Journal of Emerging Trends in Engineering Research, 8(9), September 2020, $5661-5667$

21. B. Geddes, H. Leon, and X. Huang.Superalloy: Alloying and Performance, Ohio: ASM International, 2010.

22. C.H. Hong, Y. H Shek, N. H Heo, S. J. Kim.Coherent or Incoherent Transition of Precipitate during Rupture Test in TP347H Austenitic Stainless Steels, Materials Characterization, vol. 115, pp. 71-82, 2016.

23. Iasechko, M., Larin, V., Maksiuta, D., (...), Zinchenko, A., Vozniak, R. Model description of the modified solid state plasma material for electromagnetic radiation protection, International Journal of Emerging Trends in Engineering Research 7(10), pp. 376-382, 2019.
24. Turinskyi, O., Iasechko, M., Larin, V., (...), Tarshyn, V., Dziubenko, Y. The investigation of the impulse evolution of the radio-frequency and optical radiation during the interaction with the solid-state plasma media on radioisotope and hexaferrite inclusions,International Journal of Emerging Trends in Engineering Research 8(2),47, pp. 568-573, 2020

25. Darmawan, A.S., Siswanto, W.A., Sujitno, T. Comparison of commercially pure titanium surface hardness improvement by plasma nitrocarburizing and ion implantation, Advanced Materials Research, 789, pp. 347-351, 2013. 